\title{
EFFECT OF INTELLECTUAL CAPITAL, CAPITAL STRUCTURE AND MANAGERIAL OWNERSHIP TOWARD FIRM VALUE OF MANUFACTURING SECTOR COMPANIES LISTED IN INDONESIA STOCK EXCHANGE (IDX) PERIOD 2010-2014
}

\author{
Hamidah \\ Faculty of Economics, University of Jakarta \\ Email: hamidah@unj.ac.id \\ Gatot Nazir Ahmad \\ Faculty of Economics, University of Jakarta \\ Email: ahmad72nazir@gmail.com \\ Rahma Aulia \\ Management Faculty of Economics, University of Jakarta \\ Email: rahmaaulia2995@gmail.com
}

\begin{abstract}
The purpose of this study is to know the effect of Intellectual Capital, Capital Structure and Managerial Ownership on Firm Value in Manufacturing Company Listed on Indonesia Stock Exchange in 2010-2014. In this research, intellectual capital can be seen from VACA (Value Added Capital Employed), VAHU (Value Added Human Capital), and STVA (Structural Capital Value Added). The research model in this study employs panel data analysis. The samples are manufacturing companies listed in Indonesian Stock Exchange in 2010-2014 selected by purposive sampling. The result show that VACA and STVA has negative and not significant effect on firm value (Tobins' $Q$ ). Whereas, VAHU have positive and not significant effect on firm value. Capital structure (DAR) have positive and significant effect on firm value. Managerial ownership (MGRL) have negative and significant effect on firm value.
\end{abstract}

Keywords: Firm Value, Intellectual Capital, VACA, VAHU, STVA, Capital Structure, Managerial Ownership. 


\section{PENDAHULUAN}

Perekonomian Indonesia terus tumbuh setiap tahunnya, Media Industri menyatakan pada tahun 2015 ekonomi Indonesia tumbuh 4,8 persen, lebih rendah dibandingkan dengan tahun sebelumnya 5,02 persen. Kelesuan ini menimbulkan kecemasan bagi para pelaku industri. Selain itu, harga komunitas tambang, seperti minyak mentah dan baru bara, juga masih rendah sehingga menekan harga komoditas lainnya. Hal tersebut, berdampak kepada pendapatan masyarakat yang menurun sehingga daya beli konsumen akan merosot. Ditambah perdagangan bebas ASEAN atau Masyarakat Ekonomi ASEAN (MEA) telah berlaku pada tahun 2016. Pada kondisi seperti ini setiap perusahaan harus memikirkan strategi untuk menghadapi situasi ekonomi yang terjadi.

Sebuah perusahaan ada karena kegiatan ekonomi yang mereka lakukan seperti produksi dan distribusi memberi manfaat kepada pemilik, pekerja, dan sumber daya lainnya. Salah satu tujuan utama manajer perusahaan adalah memaksimalkan nilai perusahaan. Nilai perusahaan adalah pusat dari keuangan perusahaan, namun, untuk menghitung nilai perusahaan tidaklah mudah (Berzkalne dan Zelgave, 2014:887). Nilai perusahaan sering dihubungkan dengan kinerja pasar perusahaan atau harga saham perusahaan. Nilai perusahaan merupakan hal yang penting dan perlu ditingkatkan untuk kepentingan shareholders dan stakeholder. Sehingga memahami faktor - faktor yang dapat mempengaruhi nilai perusahaan adalah hal yang penting.

Keberhasilan perusahaan dimasa lalu sangat tergantung pada penggunaan aset berwujud (tangible asset): lahan, sumber daya alam, peralatan dan lainnya yang digunakan untuk dapat menciptakan nilai tambah. Namun, di era sekarang lingkungan bisnis telah berkembang dari era industri ke era informasi. The Economics Institute of Washington, d.c., mencatat bahwa nilai ekonomi dari produktivitas suatu negara tergantung pada keterampilan dan pengetahuan tenaga kerja, kemampuan perusahaan dalam memecahkan masalah bisnis, yang pada gilirannya akan mendorong nilai perusahaan. Sehingga perusahaan harus memiliki keunggulan kompetitif, jika ingin memenangkan kompetisi di era bebas ini (Nuryaman, 2015:292). 
Berdasarkan uraian dan permasalahan nilai perusahaan diatas, sangat penting untuk mempertimbangkan faktor-faktor yang mempengaruhi nilai perusahaan. Cukup banyak penelitian yang telah dilakukan untuk mengidentifikasi faktor-faktor yang mempengaruhi nilai perusahaan. Dalam penelitian ini variabel yang akan dibahas terbatas pada modal intelektual, struktur modal, dan kepemilikan manajerial.

Studi mengenai mengenai nilai perusahaan, ditemukan hasil yang cukup beragam. Variabel modal intelektual salah satunya, Nuryaman (2015) menyatakan dalam penelitiannya modal intelektual adalah aset perusahaan yang dapat membuat keunggulan perusahaan dalam persaingan global, sebagai aset tidak berwujud yang dapat meningkatkan keunggulan kompetitif perusahaan. Ini menunjukan bahwa pasar atau investor memberikan nilai yang lebih tinggi untuk perusahaan yang memiliki modal intelektual lebih besar.

Untuk aset berwujud, dalam penelitian ini penulis akan membahas mengenai struktur modal. Kebijakan struktur modal melibatkan adanya suatu pertukaran antara risiko dan pengembalian. Penggunaan lebih banyak utang akan meningkatkan risiko yang ditanggung oleh para pemegang saham. Namun, penggunaan utang yang lebih besar biasanya akan menyebabkan terjadinya ekspektasi tingkat pengembalian atas ekuitas yang lebih tinggi. Risiko yang lebih tinggi cenderung akan menurunkan harga saham, tetapi ekspektasi tingkat pengembalian yang lebih tinggi akan menaikkannya. Karena itu, stuktur modal yang optimal harus mencapai suatu keseimbangan antara risiko dan pengembalian (Brigham dan Houston, 2011: 171).

Dalam proses memaksimalkan nilai perusahaan akan muncul konflik kepentingan antara manajer dan pemegang saham (pemilik perusahaan) yang sering disebut agency problem. Agency problem seringkali timbul karena penyatuan kepentingan pemegang saham pada struktur kepemilikan (Bemby et al, 2015:149). Konflik antara manajer dan pemegang saham atau yang sering disebut dengan masalah keagenan dapat diminimumkan dengan suatu mekanisme pengawasan yang dapat mensejajarkan kepentingan-kepentingan tersebut sehingga timbul biaya keagenan (agency cost). Ada beberapa alternatif untuk 
mengurangi agency cost, diantaranya dengan adanya kepemilikan saham oleh manajemen dan kepemilikan saham oleh institusional (Bemby et al, 2015: 151). Dengan kepemilikan saham oleh manajerial, diharapkan manajer akan bertindak sesuai dengan keinginan para principal karena manajer akan termotivasi untuk meningkatkan kinerja dan nantinya dapat meningkatkan nilai perusahaan.

Penelitian oleh Mule et al (2015) menemukan bahwa struktur kepemilikan memiliki pengaruh positif terhadap nilai pasar. Dimana ketika terjadi perubahan pada struktur kepemilikan memacu peningkatan yang terjadi pada Tobin's Q. Sementara itu penelitian dari Ruan et al (2011) menyimpulkan bahwa variabel kepemilikan manajerial memiliki pengaruh dengan arah hubungan negatif. Hal ini dapat dikatakan bahwa semakin tinggi proporsi kepemilikan manajerial, akan menurunkan market value. Hasil tersebut konsisten dengan Bemby et al (2015) dan Al-Saidi dan Al-Shammari (2014). Penurunan market value ini diakibatkan karena tindakan opportunistic yang dilakukan oleh para pemegang saham managerial. Meskipun ada banyak penelitian mengenai struktur kepemilikan tetapi hasil-hasil dari penelitian tersebut banyak yang saling bertentangan satu sama lain.

\section{KAJIAN TEORI}

\section{Resource Based Theory (RBT)}

Resource Based Theory (RBT) menjelaskan bahwa perusahaan akan mendapatkan keuntungan kompetitif dengan memanfaatkan sumber daya yang memenuhi kriteria tertentu yang telah ditentukan. Sehingga penting untuk memaksimalkan modal intelektual untuk mendorong nilai perusahaan (Bemby et al, 2015:150).

\section{Resourse Based View (RBV)}

Resourse Based View (RBV) menyatakan bahwa sumber daya perusahaan, terutama yang tidak berwujud lebih mungkin untuk berkontribusi untuk pencapaian perusahaan (Hsu dan Wang, 2011:1). 


\section{Stakeholder Theory}

Stakeholder Theory, menyatakan manajemen organisasi diharapkan untuk melakukan aktifitas yang dianggap penting oleh stakeholder mereka dan melaporkan kembali aktifitas-aktifitas tersebut pada stakeholder. Tujuan utama dari teori stakeholder adalah untuk membantu manajer korporasi mengerti lingkungan stakeholder mereka dan melakukan pengelolaan dengan lebih efektif di antara keberadaan hubungan-hubungan di lingkungan perusahaan mereka. Namun demikian, tujuan yang lebih luas dari teori stakeholder adalah untuk menolong manajer korporasi dalam meningkatkan nilai dari dampak aktifitasaktifitas mereka dan meminimalkan kerugian-kerugian bagi stakeholder. Pada kenyataannya, inti keseluruhan teori stakeholder terletak pada apa yang akan terjadi ketika korporasi dan stakeholder menjalankan hubungan mereka (Hamidah: 2014).

\section{Legitimacy Theory}

Legitimacy Theory, Teori legitimasi berhubungan erat dengan teori stakeholder, teori legitimasi menyatakan bahwa organisasi secara berkelanjutan mencari cara untuk menjamin operasi mereka berada dalam batas dan norma yang berlaku di masyarakat (Hamidah: 2014).

\section{Knowledge Based Theory}

Knowledge Based Theory, membentuk dasar untuk membangun keterlibatan modal manusia dalam kegiatan rutin perusahaan. Hal ini dicapai melalui peningkatan keterlibatan karyawan dalam perumusan tujuan operasional dan jangka panjang perusahaan.

\section{Trade-off theory}

Teori trade-off berpendapat bahwa perusahaan melakukan trade-off pada suatu keuntungan, costs of debt, equity financing, dan mencapai struktur modal yang optimal bahkan dengan ketidaksempurnaan pasar seperti pajak, biaya kebangkrutan dan biaya agensi (Hasan et al, 2014:185). Keuntungannya perusahaan dapat meminjam lebih sampai tingkat tertentu, karena setelah itu 
profitabilitas dan nilai perusahaan akan menurun karena interaksi biaya kebangkrutan dan biaya agensi.

Trade-off theory menunjukkan bahwa struktur modal yang optimal memang ada. Memaksimalkan nilai perusahaan akan menemukan struktur modal yang optimal oleh keuntungan perdagangan dan biaya dari pembiayaan utang (Coung, 2014:16). Berdasarkan trade-off theory keputusan perusahaan menggunakan utang didasarkan pada keseimbangan antara penghematan pajak dan biaya kesulitan keuangan. Selain itu, trade-off theory menjelaskan untuk mengevaluasi alternatif pendanaan didasarkan pada pertimbangan penghematan pajak, biaya kesulitan keuangan, dan biaya keagenan (Sudana, 2011:153). Trade-off theory juga mengasumsikan bahwa investor dan manajemen memiliki informasi yang sama sehingga menghambat kemampuan perusahaan untuk melakukan penambahan dana.

\section{Pecking order theory}

Pecking order theory menunjukkan bahwa ada hierarki preferensi perusahaan sehubungan dengan pembiayaan investasi mereka dan tidak ada yang terdefinisi dengan baik mengenai sasaran debt ratio. Kesimpulan yang ditarik dari teori pecking order adalah bahwa ada hierarki preferensi perusahaan sehubungan dengan pembiayaan investasi mereka. Teori ini menunjukkan bahwa perusahaan membiayai kebutuhan mereka, awalnya dengan menggunakan dana internal, contohnya adalah laba yang tidak dibagikan, di mana tidak ada information asymmetry, berikutnya utang kurang berisiko jika dana tambahan yang dibutuhkan, dan terakhir dengan masalah ekuitas eksternal yang berisiko untuk menutupi kebutuhan modal yang tersisa. Urutan preferensi mencerminkan biaya relatif keuangan untuk menempatkan berbagai sumber pembiayaan. Oleh karena itu, teori pecking order menunjukkan hubungan negatif antara profitabilitas dan utang (Coung, 2014:16).

\section{Agency Theory}

Shareholders adalah pemilik dari perusahaan, mereka membeli saham karena mereka mencari keuntungan finansial dari perusahaan tersebut. Dalam 
banyak kasus, shareholders memilih direksinya sendiri, yang kemudian mempekerjakan manajerial untuk menjalankan perusahaan dari hari ke hari. Ketika manajerial bekerja atas nama pemegang saham, maka mereka harus mengejar kebijakan yang dapat meningkatkan nilai dari pemegang saham (Brigham dan Houston, 2011). Dan terdapat kemungkinan manajerial memiliki tujuan pribadi yang akan bersaing dengan kepentingan untuk memaksimalkan kekayaan pemegang saham. Manajerial dipekerjakan oleh pemilik perusahaan (shareholders), untuk membuat keputusan dan dapat terjadi konflik kepentingan yang biasa diketahui agency theory.

\section{Value Added Intellectual Coefficient (VAIC'M)}

Metode VAICTM dikembangkan oleh Pulic (1998), didisain untuk menyajikan informasi tentang value creation efficiency dari aset berwujud dan aset tidak berwujud yang dimiliki perusahaan. Model ini dimulai dengan kemampuan perusahaan untuk menciptakan value added (VA). VA dihitung sebagai selisih antara output dan input.

Outputs (OUT) merepresentasikan revenue dan mencakup seluruh produk dan jasa yang dijual di pasar. Inputs (IN) mencakup seluruh beban yang digunakan dalam memperoleh revenue. Hal penting dalam model ini adalah bahwa beban karyawan (labour expenses) tidak termasuk dalam IN, karena peran aktifnya dalam proses value creation, intellectual potential (yang direpresentasikan dengan labour expenses) tidak dihitung sebagai biaya. Aspek kunci dalam model Pulic's adalah memperlakukan tenaga kerja sebagai entitas penciptaan nilai (value creating entity). Hasilnya adalah bahwa VA mengekspresikan the new created wealth of a period.

\section{Value Addded Capital Employed (VACA)}

VACA adalah indikator untuk VA yang diciptakan oleh satu unit dari physical capital. Pulic mengasumsikan bahwa jika 1 unit dari Capital Employed menghasilkan return yang lebih besar daripada perusahaan yang lain, maka berarti perusahaan tersebut lebih baik dalam memanfaatkan Capital Employed-nya. 
Dengan demikian, pemanfaatan Capital Employed yang lebih baik merupakan bagian dari Intellectual Capital perusahaan.

\section{Value Added Human Capital (VAHU)}

Value Added Human Capital (VAHU) menunjukkan berapa banyak VA dapat dihasilkan dengan dana yang dikeluarkan untuk tenaga kerja. Hubungan antara VA dan HC mengindikasikan kemampuan dari HC untuk menciptakan nilai di dalam perusahaan. Human capital akan meningkat jika perusahaan mampu mengoptimalkan pengetahuan yang dimiliki karyawan.

\section{Structural Capital Value Added (STVA)}

Structural Capital Value Added (STVA), yang menunjukan kontribusi structural capital (SC) dalam penciptaan nilai. Rasio ini mengukur jumlah structural capital (SC) yang dibutuhkan untuk menghasilkan 1 unit dari value added yang merupakan indikasi seberapa berhasil SC dalam penciptaan nilai. Structural capital meliputi beberapa hal seperti sistem operasional, budaya organisasi, filosofi manajemen serta intellectual capital lain yang mempengaruhi proses kinerja karyawan. Perusahaan yang memiliki sumber daya karyawan yang baik jika tidak didukung dengan sistem yang bagus maka perusahaan tidak dapat mengoptimalkan potensi yang dimiliki karyawan.

\section{Nilai Perusahaan}

Nilai perusahaan merupakan persepsi investor terhadap tingkat keberhasilan perusahaan dalam mengelola sumber daya yang tercermin pada harga saham perusahaan. Sehingga dapat dikatakan bahwa harga saham merupakan cerminan dari nilai perusahaan. Semakin tinggi harga saham maka akan semakin tinggi pula nilai perusahaan, sebaliknya ketika harga saham semakin rendah maka nilai perusahaan juga akan memburuk atau kinerja perusahaan sedang kurang baik.

Tujuan utama perusahaan seperti pada theory of the firm adalah untuk memaksimumkan nilai perusahaan (value of the firm). Memaksimalkan nilai perusahaan sangat penting bagi perusahaan, karena dengan memaksimalkan nilai 
perusahaan berarti juga memaksimalkan kemakmuran pemegang saham yang merupakan tujuan utama perusahaan. Harga saham dan nilai perusahaan mengikhtisarkan penilaian kolektif investor tentang seberapa baikkah keadaan suatu perusahaan, baik kinerja saat ini maupun prospek masa depannya. Oleh sebab itu, peningkatan harga saham mengirimkan sinyal positif dari investor kepada manajer.

\section{Debt Assets Ratio (DAR)}

Debt to Total Asset Ratio (DAR) adalah untuk mengukur seberapa besar jumlah aktiva perusahaan dibiayai dengan total hutang. Semakin tinggi rasio ini berarti semakin besar jumlah modal pinjaman yang digunakan untuk investasi pada aktiva guna menghasilkan keuntungan bagi perusahaan.

\section{Kepemilikan Manajerial}

Dengan adanya kepemilikan manajemen dalam sebuah perusahaan akan menimbulkan dugaan yang menarik bahwa nilai perusahaan meningkat sebagai akibat kepemilikan manajemen yang meningkat. Kepemilikan oleh manajemen yang besar akan efektif memonitoring aktivitas perusahaan. Pada penelitian Bemby et al (2015) kepemilikan manajerial adalah ukuran persentase kepemilikan saham yang dimiliki oleh manajer, direktur, dan komisaris. Variabel ini diukur dengan persentase saham yang dimiliki pada akhir manajerial tahun bersangkutan.

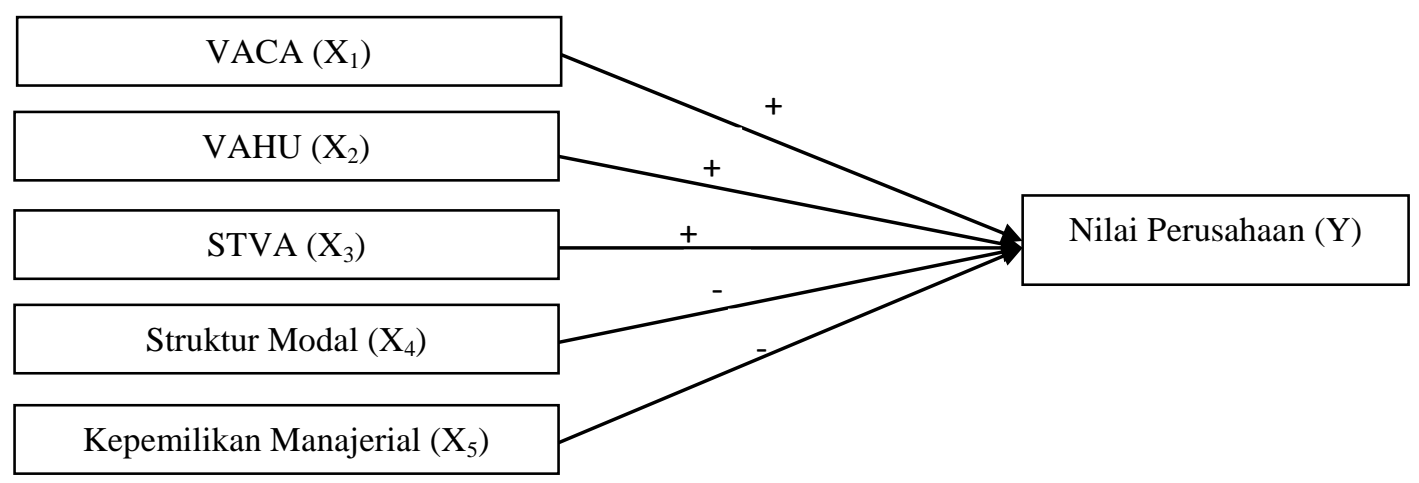

Gambar 1. Model Penelitian

Sumber: Data diolah peneliti (2016) 
$\mathrm{H}_{1}$ : VACA berpengaruh positif dan signifikan terhadap nilai perusahaan pada perusahaan manufaktur yang terdaftar dalam BEI Tahun 2010-2014

$\mathrm{H}_{2}$ : VAHU berpengaruh positif dan signifikan terhadap nilai perusahaan pada perusahaan manufaktur yang terdaftar dalam BEI Tahun 2010-2014

$\mathrm{H}_{3}$ : STVA berpengaruh positif dan signifikan terhadap nilai perusahaan pada perusahaan manufaktur yang terdaftar dalam BEI Tahun 2010-2014

$\mathrm{H}_{4}$ : Struktur modal berpengaruh negatif dan signifikan terhadap nilai perusahaan pada perusahaan manufaktur yang terdaftar dalam BEI Tahun 2010-2014

$\mathrm{H}_{5}$ : Kepemilikan manajerial berpengaruh negatif dan signifikan terhadap nilai perusahaan pada perusahaan manufaktur yang terdaftar dalam BEI Tahun 2010-2014

\section{METODE PENELITIAN}

Metode penelitian ini menggunakan metode penelitian kuantitatif asosiatif yaitu metode penelitian untuk mengetahui hubungan antara dua variabel atau lebih dalam model. Data penelitian yang diperoleh akan diolah, dianalisis secara kuantitatif serta diproses lebih lanjut dengan alat bantu program Eviews dan SPPS serta dasar-dasar teori yang telah dipelajari sebelumnya sehingga dapat memperjelas gambaran mengenai objek yang diteliti dan kemudian dari hasil tersebut akan ditarik kesimpulan.

Objek dalam penelitian ini adalah perusahaan go public sektor manufaktur yang terdaftar di Bursa Efek Indonesia (BEI). Penelitian ini meneliti dan menganalisis pengaruh modal intelektual, struktur modal, dan kepemilikan manajerial terhadap nilai perusahaan pada sektor manufaktur yang terdaftar di Bursa Efek Indonesia (BEI) periode tahun 2010-2014. Data yang digunakan dalam penelitian ini adalah data sekunder. Data penelitian ini diperoleh dari berbagai sumber diantaranya http://www.idx.co.id/, Indonesian Capital Market Directory (ICMD), Saham OK, maupun situs lain yang menyediakan data yang dibutuhkan oleh peneliti. 


\section{Variabel Penelitian dan Pengukurannya}

Penelitian ini menggunakan data sekunder yaitu Tobin's $Q$ untuk mengukur nilai perusahaan, VAICTM untuk mengukur modal intelektual, DAR untuk struktur modal, serta ukuran persentase kepemilikan saham yang dimiliki oleh manajerial. Data yang digunakan merupakan data sekunder yang diperoleh dari http://www.idx.co.id/.

\section{Metode Penentuan Populasi dan Sampel}

Populasi penelitian ini adalah seluruh perusahaan manufaktur yang terdaftar dalam Bursa Efek Indonesia (BEI) periode tahun antara 2010-2014 yang berjumlah 124 perusahaan. Penelitian ini menggunakan metode purposive sampling dalam menentukan sample, dengan tujuan mendapatkan sample yang representatif sesuai dengan kriteria yang ditentukan. Adapun kriteria sampel yang akan digunakan adalah sebagai berikut:

1. Perusahaan manufaktur yang terdaftar berturut-turut di Bursa Efek Indonesia (BEI) berturut-turut selama periode tahun 2010 sampai dengan tahun 2014. Kriteria ini dipilih karena untuk menentukan sampel penelitian, maka perusahaan harus terdaftar 5 tahun berturut-turut tanpa keluar masuk bursa.

2. Perusahaan manufaktur yang konsisten mempublikasikan laporan keuangan yang telah di audit selama periode penelitian tahun 2010-2014.

3. Perusahaan manufaktur yang memiliki data lengkap terkait dengan variabelvariabel yang digunakan dalam penelitian yaitu memiliki data untuk menghitung modal intelektual, struktur modal, dan kepemilikan manajerial.

4. Perusahaan manufaktur yang laporan tahunan menggunakan nilai mata uang rupiah selama periode 2010 sampai dengan 2014. Kriteria ini dipilih untuk menyamakan perhitungan data dalam satuan mata uang rupiah.

Berdasarkan kriteria tersebut terpilih 26 perusahaan manufaktur yang terdaftar dalam Bursa Efek Indonesia. Dengan periode pengamatan selama 5 tahun sehingga terdapat total pengamatan sebanyak 130 pengamatan.

Pengujian normalitas menggunakan uji statistik Jarque-Bera (JB). Pada hasil uji normalitas menunjukan probabilitas Jarque-Bera sebesar 0.072749 . 
Sehingga dengan hasil probabilitas Jarque-Bera lebih besar dari 0,05 maka data tersebut tidak terdapat residual. Pengujian multikolinieritas dapat dideteksi dengan menggunakan Pearson Correlation. Dari hasil pengujian tidak ada nilai korelasi yang lebih besar dari 0,8 sehingga data memiliki multikolinieritas yang lemah.

\section{Metode Analisis}

Metode analisis data yang digunakan dalam penelitian ini adalah regresi data panel. Karena data yang digunakan pada penelitian ini merupakan gabungan dari data time series dan cross section. Untuk mempermudah pengolahan data, peneliti dibantu oleh program Eviews dan SPSS.

Persamaan regresi dalam penelitian ini adalah:

\section{Nilai Perusahaan}

TOBINSQ $_{i t}=\beta_{0}+\beta_{1} \mathrm{VACA}_{i t}+\beta_{2} \mathrm{VAHU}_{i t}+\beta_{3} \mathrm{STVA}_{i t}+\beta_{4} \mathrm{DAR}_{i t}+\beta_{5} \mathrm{MGRL}_{i t}+$ $\varepsilon_{i t}$

\section{Keterangan:}

TOBINSQ : Nilai Perusahaan

VACA :Value added capital employed

VAHU : Value added human capital

STVA : Structural capital value added

DAR : Struktur modal

MGRL : Kepemilikan manajerial

$i \quad$ : data cross-section (perusahaan)

$t \quad:$ data time-series (tahun)

\section{HASIL PENELITIAN DAN PEMBAHASAN}

\section{Analisis Deskriptif}

Deskripsi data dalam penulisan ini menggunakan analisis statistik deskriptif. Statistik deskriptif yang digunakan dalam analisis ini meliputi analisis mean, minimum, maksimum dan standar deviasi. Analisis deskriptif dilakukan untuk memberi gambaran mengenai sebaran data penelitian sehingga data 
penelitian mudah dipahami. Pada tabel dibawah ini disajikan statistik deskriptif untuk TOBINSQ, VACA, VAHU, STVA, DAR, MGRL pada perusahaan manufaktur tahun 2010-2014.

Tabel 1. Statistik Deskriptif Variabel Penelitian

\begin{tabular}{|l|c|c|c|c|c|c|}
\hline & TOBINSQ & VACA & VAHU & STVA & DAR & MGRL \\
\hline Mean & 1.190119 & 0.209547 & 4.115156 & 0.613888 & 0.469293 & 0.064714 \\
\hline Median & 0.961195 & 0.169200 & 2.509533 & 0.663288 & 0.465415 & 0.016039 \\
\hline Maximum & 4.906135 & 3.558355 & 29.32274 & 3.891017 & 1.107059 & 0.256198 \\
\hline Minimum & 0.364607 & -0.931005 & -4.926064 & -5.874384 & 0.037232 & $5.06 \mathrm{E}-06$ \\
\hline Std. Dev. & 0.697591 & 0.342562 & 5.638351 & 0.805677 & 0.242549 & 0.082056 \\
\hline
\end{tabular}

Sumber: Data diolah oleh peneliti (2016)

\section{Analisis Regresi}

\section{Tabel 2. Hasil Regresi Data Panel}

Dependent Variable: TOBINSQ?

Method: Pooled EGLS (Cross-section random effects)

Date: 06/07/16 Time: 07:10

Sample: 20102014

Included observations: 5

Cross-sections included: 23

Total pool (unbalanced) observations: 107

Swamy and Arora estimator of component variances

Cross sections without valid observations dropped

\begin{tabular}{|c|c|c|c|c|}
\hline Variable & Coefficient & Std. Error & t-Statistic & Prob. \\
\hline $\mathrm{C}$ & 0.712638 & 0.082016 & 8.689044 & 0.0000 \\
\hline VACA? & -0.018890 & 0.044850 & -0.421188 & 0.6745 \\
\hline VAHU? & 0.007010 & 0.004054 & 1.729163 & 0.0868 \\
\hline STVA? & -0.012271 & 0.017285 & -0.709924 & 0.4794 \\
\hline DAR? & 0.599353 & 0.106674 & 5.618562 & 0.0000 \\
\hline MGRL? & -1.029046 & 0.397507 & -2.588751 & 0.0111 \\
\hline \multicolumn{5}{|c|}{ Random Effects (Cross) } \\
\hline _SKLT-C & -0.023728 & & & \\
\hline -TBLA-C & 0.082793 & & & \\
\hline RDTX $-\mathrm{C}$ & -0.010433 & & & \\
\hline SSTM-C & -0.160477 & & & \\
\hline SRSN-C & 0.272431 & & & \\
\hline AKRA $-\mathrm{C}$ & 0.241737 & & & \\
\hline ETWA-C & -0.102665 & & & \\
\hline LTLS-C & -0.118020 & & & \\
\hline _INCI-C & -0.199704 & & & \\
\hline _YPAS-C & 0.174193 & & & \\
\hline _ALMI-C & -0.225446 & & & \\
\hline JPRS $-\mathrm{C}$ & 0.191035 & & & \\
\hline \multicolumn{5}{|l|}{ (lanjutan) } \\
\hline
\end{tabular}




\begin{tabular}{|c|c|c|c|}
\hline & & & \\
\hline$-\mathrm{LMSH}-\mathrm{C}$ & & & \\
\hline _LION-C & 0.314929 & & \\
\hline _KICI-C & -0.192759 & & \\
\hline _MLIA $-\mathrm{C}$ & -0.239595 & & \\
\hline _KBLM-C & -0.077170 & & \\
\hline _MTDL--C & -0.112339 & & \\
\hline IINDS--C & 0.039863 & & \\
\hline _INTA--C & -0.017571 & & \\
\hline _NIPS--C & 0.007594 & & \\
\hline _PRAS--C & -0.292877 & & \\
\hline _PYFA--C & 0.247866 & & \\
\hline & Effects $\mathrm{Sp}$ & cification & \\
\hline & & S.D. & Rho \\
\hline Cross-section random & & 0.187546 & 0.6383 \\
\hline Idiosyncratic random & & 0.141169 & 0.3617 \\
\hline & Weighted & Statistics & \\
\hline R-squared & 0.313970 & Mean dependent var & 0.306849 \\
\hline Adjusted R-squared & 0.280008 & S.D. dependent var & 0.183152 \\
\hline S.E. of regression & 0.144814 & Sum squared resid & 2.118080 \\
\hline F-statistic & 9.244763 & Durbin-Watson stat & 1.269662 \\
\hline Prob(F-statistic) & 0.000000 & & \\
\hline & Unweighte & Statistics & \\
\hline R-squared & 0.127457 & Mean dependent var & 0.937774 \\
\hline Sum squared resid & 5.935525 & Durbin-Watson stat & 0.453076 \\
\hline
\end{tabular}

Sumber: Data diolah peneliti menggunakan Eviews 9

\section{Pengaruh VACA terhadap nilai perusahaan}

Nilai koefisien dari variabel VACA adalah -0.018890 mempunyai arti bahwa VACA berpengaruh negatif terhadap nilai perusahaan. Nilai probability pada variabel VACA adalah 0.6745 nilai tersebut lebih besar dari 0,05. Sehingga VACA berpengaruh negatif tidak signifikan terhadap nilai perusahaan, dimana $\mathrm{H}_{1}$ ditolak. Hal ini menandakan bahwa setiap kenaikan 1 satuan pada VACA maka TOBINSQ turun sebesar -0.018890 satuan. Serta, menunjukan rata-rata perusahaan manufaktur yang terdaftar di BEI pada periode tersebut belum dapat memanfaatkan modal yang tersedia pada perusahaan secara optimal untuk meningkatkan nilai perusahaan, sehingga TOBINSQ pun menurun.

Hasil penelitian ini tidak sesuai dengan Stakeholder Theory, yang menyatakan bahwa para stakeholder berkepentingan untuk mempengaruhi manajemen dalam proses pemanfaatan seluruh potensi yang dimiliki organisasi. 
Stakeholder Theory menyatakan dengan pengelolaan yang baik dan maksimal atas seluruh potensi inilah organisasi akan dapat menciptakan value added untuk meningkatkan nilai perusahaan yang merupakan orientasi para stakeholder. Hasil penelitian ini sesuai dengan penelitian yang dilakukan oleh Rezaei (2013) dan Nuryaman (2015). Hasil penelitian ini bertentangan dengan penelitian yang dilakukan oleh Berzkalne dan Zelgalve (2014).

\section{Pengaruh VAHU terhadap nilai perusahaan}

Nilai koefisien dari variabel VAHU adalah 0.007010 mempunyai arti bahwa VAHU berpengaruh positif terhadap nilai perusahaan. Jika VAHU mengalami peningkatan 1 satuan maka akan meningkatkan TOBINSQ sebesar 0.007010 kali. Nilai probability pada variabel VAHU adalah 0.0868 , nilai tersebut lebih besar dari 0,05. Sehingga $\mathrm{H}_{2}$ ditolak karena VAHU berpengaruh positif dan tidak signifikan terhadap nilai perusahaan. Hal ini menandakan ratarata perusahaan manufaktur yang terdaftar di BEI pada periode tersebut tidak berpengaruh signifikan terhadap nilai perusahaan karena dengan VAHU yang terus meningkat akan membuat semakin tinggi pula beban usaha perusahaan karena peningkatan beban gaji untuk karyawan. Serta, menunjukan hubungan yang tidak langsung antara modal intelektual dengan nilai perusahaan. Karena ketika perusahaan menambah investasinya kepada karyawan tidak memberikan dampak langsung kepada nilai perusahaan. Dalam hal ini perlu variabel interverning untuk melihat pengaruhnya.

Hasil penelitian ini sesuai dengan penelitian yang dilakukan oleh Nuryaman (2015) yang menyatakan hubungan yang tidak signifikan terhadap nilai perusahaan. Hasil penelitian ini bertentangan dengan penelitian yang dilakukan oleh Maditinos et al (2011) dan Berzkalne dan Zelgalve (2014).

\section{Pengaruh STVA terhadap nilai perusahaan}

Nilai koefisien dari variabel STVA adalah -0.012271 mempunyai arti bahwa STVA berpengaruh negatif terhadap nilai perusahaan. Hal ini menandakan bahwa setiap kenaikan 1 satuan pada STVA, maka nilai perusahaan akan turun sebesar 0.012271 satuan. Nilai probability pada variabel STVA adalah 0.4794 nilai tersebut lebih besar dari 0,05. Sehingga $\mathrm{H}_{3}$ ditolak karena STVA 
berpengaruh negatif tidak signifikan terhadap nilai perusahaan. Kesimpulannya rata-rata perusahaan manufaktur yang terdaftar di BEI pada periode tersebut belum dapat meningkatkan pengetahuan para karyawannya dengan mengembangkan modal struktural yang dimiliknya dengan maksimal untuk meningkatkan nilai perusahaan, sehingga TOBINSQ pun menurun.

Hasil penelitian ini tidak sesuai dengan Knowledge Based Theory yang menyatakan bahwa peran perusahaan mengembangkan pengetahuan baru yang penting untuk keunggulan kompetitif. Namun jika perusahaan tidak dapat mengembangkan pengetahuan baru maka perusahaan tersebut tidak dapat memperoleh keunggulan kompetitif (Hamidah, 2014).

Hasil penelitian ini sesuai dengan penelitian yang dilakukan oleh Maditinos et al (2011) yang menyatakan tidak terdapat pengaruh yang signifikan terhadap nilai perusahaan.

\section{Pengaruh Struktur Modal terhadap nilai perusahaan}

Nilai koefisien dari variabel struktur modal adalah 0.599353 mempunyai arti bahwa struktur modal berpengaruh positif terhadap nilai perusahaan. Hal ini menandakan bahwa setiap kenaikan 1 satuan pada DAR maka TOBINSQ akan naik sebesar 0.599353 satuan. Nilai probability pada variabel struktur modal adalah 0.0000 nilai tersebut lebih kecil dari 0,05. Sehingga $\mathrm{H}_{4}$ ditolak, karena struktur modal berpengaruh positif dan signifikan terhadap nilai perusahaan. Hal ini berarti semakin besar rasio struktur modal, maka semakin besar pula kemungkinan perusahaan untuk meningkatkan nilai perusahaannya. Kesimpulannya rata-rata perusahaan manufaktur yang terdaftar di BEI pada periode tersebut menggunakan utang untuk membantu meningkatkan kinerja dan nilai perusahaan.

Hasil penelitian ini sesuai dengan Trade-off Theory yang menyatakan bahwa perusahaan akan memaksimalkan nilai perusahaan dengan menemukan struktur modal yang optimal oleh pembiayaan utang (Coung, 2014). Serta sesuai dengan penelitian yang dilakukan oleh Modigliani dan Miller yang mengasumsikan bahwa perusahaan yang menggunakan hutang akan memiliki pajak hutang. Dimana dengan adanya pajak ini, Modigliani dan Miller 
menyimpulkan akan meningkatkan nilai perusahaan karena dengan biaya bunga hutang akan mengurangi pembayaran pajak.

Hasil penelitian ini sesuai dengan penelitian Mule et al (2015) dan Wahba (2014) yang menyatakan terdapat pengaruh yang signifikan terhadap nilai perusahaan. Serta bertentangan dengan penelitian yang dilakukan oleh Zeitun dan Tian (2007).

\section{Pengaruh Kepemilikan Manajerial terhadap nilai perusahaan}

Nilai koefisien dari variabel kepemilikan manajerial adalah -1.029046 mempunyai arti bahwa kepemilikan manajerial berpengaruh negatif terhadap nilai perusahaan. Hal ini menandakan bahwa setiap kenaikan 1 satuan pada MGRL maka TOBINSQ turun sebesar -1.029046 satuan. Nilai probability pada variabel struktur modal adalah 0.0111 nilai tersebut lebih kecil dari 0,05. Sehingga $\mathrm{H}_{5}$ diterima, karena kepemilikan manajerial berpengaruh negatif dan signifikan terhadap nilai perusahaan.

Hasil penemuan ini menemukan ketika manajerial bekerja atas nama pemegang saham, maka mereka harus mengejar kebijakan yang dapat meningkatkan nilai dari pemegang saham (Brigham dan Houston, 2011). Dan terdapat kemungkinan manajerial memiliki tujuan pribadi yang akan bersaing dengan kepentingan untuk memaksimalkan kekayaan pemegang saham. Sehingga terjadi hubungan yang negatif antara kepemilikan manajerial dengan nilai perusahaan.

Hasil penelitian ini sesuai dengan penelitian yang dilakukan oleh Hatem (2015), yang menyatakan bahwa tingkat kepemilikan manajerial yang tinggi manajer mulai memiliki perilaku menyimpang dari perilaku manajerial untuk memaksimalkan nilai perusahaan. Serta bertentangan dengan penelitian yang dilakukan oleh Mule et. al (2015), Al-Saidi dan Al-Shammari (2014) yang menyatakan terdapat pengaruh yang tidak signifikan terhadap nilai perusahaan.

\section{Koefisien Determinasi $\left(\mathbf{R}^{2}\right)$}

Koefisien determinasi $\mathrm{R}^{2}$ (R-Square) pada persamaan regresi adalah sebesar 0.280008. Dari nilai tersebut dapat ditarik kesimpulan bahwa sebesar $28 \%$ dari variabel terikat dapat dijelaskan oleh variasi dari kelima variabel independen 
yaitu VACA, VAHU, STVA, DAR, dan Kepemilikan Manajerial, sedangkan 72\% dijelaskan oleh faktor-faktor lain diluar variabel yang diteliti pada penelitian ini.

\section{KESIMPULAN, IMPLIKASI, DAN SARAN}

\section{Kesimpulan}

Berdasarkan hasil penelitian di Bab 4 dapat ditarik kesimpulan sebagai berikut :

1. VACA merupakan proxy pertama dari modal intelektual memiliki pengaruh negatif dan tidak signifikan terhadap nilai perusahaan pada perusahaan manufaktur yang terdaftar di BEI pada tahun 2010-2014. Hal ini menunjukan perusahaan sektor manufaktur belum dapat memanfaatkan modal yang tersedia secara optimal untuk meningkatkan nilai perusahaan.

2. VAHU merupakan proxy kedua dari modal intelektual memiliki pengaruh positif dan tidak signifikan terhadap nilai perusahaan pada perusahaan manufaktur yang terdaftar di BEI pada tahun 2010-2014. Hal ini menunjukan perusahaan sektor manufaktur menginvestasikan uang kepada karyawan untuk menciptakan nilai tambah bagi perusahaan.

3. STVA merupakan proxy ketiga dari modal intelektual memiliki pengaruh negatif dan tidak signifikan terhadap nilai perusahaan pada perusahaan manufaktur yang terdaftar di BEI pada tahun 2010-2014. Hal ini menunjukan perusahaan sektor manufaktur belum dapat meningkatkan pengetahuan para karyawannya dengan mengembangkan modal struktural yang dimiliknya dengan maksimal untuk meningkatkan nilai perusahaan.

4. Struktur modal (DAR) memiliki pengaruh positif dan signifikan terhadap nilai perusahaan pada perusahaan manufaktur yang terdaftar di BEI pada tahun 2010-2014. Hal ini menandakan semakin besar rasio struktur modal, maka semakin besar pula kemungkinan perusahaan untuk meningkatkan nilai perusahaannya. Serta, menunjukan perusahaan sektor manufaktur lebih banyak menggunakan external funding.

5. Kepemilikan manajerial (MGRL) memiliki pengaruh yang negatif dan signifikan terhadap nilai perusahaan pada perusahaan manufaktur yang 
terdaftar di BEI pada tahun 2010-2014. Hal menunjukan semakin tinggi kepemilikan manajerial perusahaan akan menurunkan nilai perusahaan.

\section{Implikasi}

Implikasi yang diberikan penelitian ini untuk perusahaan maufaktur dan investor adalah:

1. Diharapkan agar perusahaan manufaktur yang terdaftar di BEI dapat memanfaatkan modal intelektual, struktur modal, dan kepemilikan manajerial untuk meningkatkan nilai perusahaan hingga perusahaan dapat memiliki keunggulan kompetitif.

2. Bagi investor diharapkan agar penelitian ini dapat memberikan informasi dalam pengambilan keputusan yang tepat. Investor harus bersikap hati-hati dalam pengambilan keputusan untuk membeli saham-saham pada perusahaan manufaktur dengan memperhatikan nilai dari modal intelektual, struktur modal, dan kepemilikan manajerial sehingga dapat mengurangi risiko yang ada.

\section{Saran}

Saran yang diberikan peneliti untuk perusahaan dan juga peneliti selanjutnya adalah:

1. Penelitian selanjutnya diharapkan memilih periode yang lebih lama agar hasil yang didapat lebih baik.

2. Penelitian selanjutnya juga diharapkan dapat menambahkan jumlah sampel penelitian atau dapat membandingkan sektor-sektor perusahaan lain yang terdaftar di BEI dalam hal kinerja perusahaan.

3. Penelitian selanjutnya diharapkan mencoba metode lain untuk mengetahui keakuratan prediksi terhadap nilai perusahaan.

4. Penelitian selanjutnya diharapkan mencoba proksi lain dari modal intelektual, struktur modal, dan kepemilikan manajerial. 


\section{DAFTAR PUSTAKA}

Al-Saidi, Mejbel., dan Al-Shammari, Bader., The Relationship between a Firm's Value and Ownership Structure in Kuwait: Simultaneous Analyses Approach. Kuwait: Canadian Center of Science and Education. Februari, 2014, 7, hal. 32-48

Bemby et al., Intellectual Capital, Firm Value and Ownership Structure as Moderating Variable: Empirical Study on Banking Listed in Indonesia Stock Exchange period 2009-2012). Palembang: Canadian Centre of Science and Education, Juni, 2015, 11, hal. 148-159

Berzkalne, Irina dan Zelgave, Elvira., Intellectual Capital and Company Value. Latvia: Social and Behavioral Sciences, 2014.

Brigham dan Houston, Dasar - dasar manajemen keuangan, Edisi 11, Buku 2, (Jakarta: Salemba Empat, 2010)

Cuong, Nguyen Thanh., Threshold Effect of Capital Structure on Firm Value: Evidence from Seafood Processing Enterprises in the South Central Region of Vietnam. Vietnam: International Journal of Finance \& Banking Studies. 2014, p.14-29

Hamidah, Sari, Dian Puspita., Mardiyati, Umi., Pengaruh Intellectual Capital terhadap Kinerja Keuangan pada Bank Go Public yang terdaftar di Bursa Efek Indonesia (BEI) Tahun 2009-2012. Jakarta: Jurnal Riset Manajemen Sains Indonesia (JRMSI), 2014

Hasan et al., Influence of Capital Structure on Firm Performance: Evidence from Bangladesh. Bangladesh: Canadian Center of Science and Education, Maret, 2014, hal. 184-194

Hatem, Ben Said., Interdependence between Managerial Ownership, Laverage and Firm Value: Theory and Empirical Validation. Tunisia: International Journal of Economics and Finance, 2015

Hsu, Li-Chang., Wang, Chao-Hung., Clarifying the Effect of Intellectual on Performane: The Mediating Role of Dynamic Capability. Taiwan: British Journal of Management, 2010, hal. 1-27

Maditinos et al., The impact of intellectual capital on firms' market value and financial performance, Greece: Journal of Intellectual Capital, 2011, hal. $132-151$

Media Industri, Prospek Industri 2016, Edisi No. 04. 2015, p.3

Mule et al., Capital Structure, Ownership structure and Firm Value: An Econometric Panel Analaysis of Firms Listed in Kenya. Kenya: Scholars Journal of Economics, Business and Management, 2015, p. 440-451 
Nuryaman, The Influence of Intellectual Capital on The Firm's Value with The Financial Performance as Intervening Variable. Bandung: Social and Behavioral Sciences, 2015

Pulic, A. "Measuring the performance of intellectual potential in knowledge economy", available at: www.measuring-ip.at/OPapers/ Pulic/Vaictxt/vaictxt.html, 1998. (accessed Februari 2016)

Rezaei, Emad., Investigating the impact of VAIC on Q and GR. Iran: European Online Journal of Natural Social Sciences, 2013

Ruan et al., Managerial Ownership, Capital Structure, and Firm Value: Evidence from China's Civilian-run Firm. Australian Accounting, Business and Finance Journal, 5(3), 2011, p.73-92

Sudana, I Made, Manajemen Keuangan Perusahaan Teori \& Praktik, Surabaya: Erlangga, 2011.

Ulum, Ihyaul., Intellectual Capital Performance Sektor Perbankan di Indonesia. Indonesia: FE UM Malang, 2008.

Zeitun, Rami., dan Tian, Gary Gang., Capital structure and corporate performance: evidence from Jordan. Jordan: The Australian Accounting Business \& Finance Journal, 2007. 